\title{
Comer à luz dos fogos de artifício: um evento gastronômico impulsionado pela crise econômica catalã
}

Eating in the light of fireworks: a gastronomic event fueled by the Catalan economic crisis

Cynthia Arantes Luderer

Pesquisadora do CECS (Centro de Estudos de Comunicação e Sociedade) da Universidade do Minho - UMinho, Braga/Portugal

E-mail:dressaramalho@yahoo.com.br

Artigo recebido em: 28-02-2019

Artigo aprovado em: 01-06-2019 


\section{RESUMO}

Os eventos gastronômicos têm se destacado na contemporaneidade e são passíveis de contribuir em vários cenários, quer quando estão relacionados aos aspectos sociais, econômicos ou culturais. Nesse sentido, o propósito deste estudo de caso foi conferir: qual o papel de um evento gastronômico quando se vive um período de crise econômica? Para tanto, o objeto selecionado para este trabalho foi um evento gastronômico criado por chefs de cozinha de Tarragona, uma cidade turística catalã. Com base nesse suporte, foi analisada a dinâmica comunicacional empregada pelos agentes envolvidos no processo de criação e organização desse evento, criado em 2010, que passou a fazer parte do cronograma turístico dessa cidade. Com cunho exploratório e qualitativo, esta pesquisa, desenvolvida em campo, apoiou-se nos princípios da Semiótica e da Análise do Discurso para examinar as narrativas dos agentes entrevistados, assim como os textos virtuais dedicados a divulgar o evento em pauta. Além de destacar o turismo da cidade, este estudo conclui que, em tempos de crise econômica, os eventos gastronômicos são apresentados como um dispositivo para estimular os agentes políticos e os gastronômicos a se unirem, como também criam uma oportunidade para os cidadãos-consumidores desfrutarem de seu tempo de ócio, num período no qual eles são limitados por questões econômicas.

Palavras-chave: Crise Econômica. Tarragona. Evento Gastronômico.

\section{ABSTRACT}

The gastronomic events have been outstanding in the contemporaneity and they are likely to contribute in several scenarios, whether they are related to the social, economic or cultural aspects. In this sense, the purpose of this case study was to check: what is the role of a gastronomic event when experiencing a period of economic crisis? For this, the object selected for this work was a gastronomic event created by chefs from Tarragona, a Catalan tourist town. Based on this support, we analysed the communication dynamics employed by the agents involved in the process of creation and organization of this event, created in 2010, which became part of the touristic schedule of that city. With an exploratory and qualitative character, this research, developed in the field, was based on the principles of Semiotics and Discourse Analysis to examine the narratives of the agents interviewed, as well as the virtual texts dedicated to publicizing the event in question. Besides highlighting the city's tourism, this study concludes that, in times of economic crisis, the gastronomic events are presented as a device to stimulate political and gastronomic agents to team up, as well as create an opportunity for citizens-consumers enjoy their leisure time, when they are constrained by economic problems.

Keywords: Economic Crisis. Tarragona. Gastronomic Event. 


\section{INTRODUÇÃO}

Uma das quatro províncias da comunidade autônoma da Catalunha é Tarragona. Sua capital, que leva esse mesmo nome, intitulada como Tarraco no início da era Cristã, era a capital romana na península hispânica. Banhada pelo Mar Mediterrânico, essa cidade oferece diferentes atrações aos seus visitantes, muitas delas desenvolvidas ao ar livre, junto ao seu peculiar conjunto arqueológico, reconhecido pela Unesco como Patrimônio da Humanidade.

O slogan "Tarragona: História Viva" condiz com o calendário de atividades culturais desse município, que reza pela produção de eventos vinculados às tradições regionais, as quais acionam diferentes setores, dentre os quais o da gastronomia (Calendario de atividades, 2019). Dos 35 programas divulgados pelo setor de turismo dessa cidade para 2019, quatro focam na alimentação e outros seis mantêm a gastronomia como coadjuvante das festas. "O Concurso Internacional de Fogos Artificiais" é um desses, pois a ele foi inserida a atração Sopars sota els focs ${ }^{l}$, o objeto de estudo a ser discutido neste trabalho.

A gastronomia é um tema emblemático para a Catalunha, e tornou-se referência neste século, quando a cozinha molecular e seu principal difusor, o premiado chef catalão Ferran Adriá, passaram a ser apresentados como paradigmas da alimentação contemporânea (Abend, 2011). As propostas desse chef, que alcançou status de celebridade, foram relevantes para mover e insuflar o espetáculo midiático gastronômico, pois suas produções, assim como as de profissionais da área que o seguiram, transformaram-se em dispositivos potenciais para atrair sibaritas que buscassem novas experiências (Luderer, 2013; Luderer \& Soares, 2017).

Nesse compasso, a Catalunha ampliou seu potencial turístico destinado ao sol e ao mar, e desenvolveu uma dinâmica relacionada ao turismo gastronômico (Londoño, 2013). Sua capital, Barcelona, situada a menos de cem quilômetros de Tarragona, tornou-se uma cidade gastronômica e a primeira gourmand fora do reduto francês (El sector turístico, 2014).

O cenário dos chefs estrelados contribui para girar o espetáculo da gastronomia e ajuda a manter ativo o livro de reservas de seus restaurantes, porém, há uma grande parte de profissionais a ladear essa posição, os quais necessitam criar estratégias para driblar diferentes tipos de crises para manter seus estabelecimentos. Além das conjunturas internas relacionadas às suas rotinas, há as externas, e ambas são passíveis para solapar seus negócios. Nesse prisma, um exemplo a ser destacado foi a recente crise econômica de 2008, a qual desafiou muitos catalães e derrocou alguns tantos do mercado da restauração.

\footnotetext{
${ }^{1}$ Jantar sob os fogos.
} 
É pertinente lembrar que, o vocábulo crise pode estar relacionado a várias acepções, mas, como ressalta Leone (2016), ele tornou-se dominante quando aplicado ao domínio da economia. No que se refere a essa crise de 2008, por exemplo, o autor esclarece que se tratou de uma "recessão mundial que atingiu em simultâneo os maiores mercados dos vários continentes" (Leone, 2016, p. 09). Por suposto, a Catalunha também foi atingida e, ainda que a região estivesse a viver sua fama gastronômica, grande parte dos agentes da restauração tiveram dificuldades para manter seus negócios ativos.

Segundo Gallego (2018), na Espanha, a crise de 2008 afetou os pequenos negócios vinculados à área de alimentação, mas também os restaurantes gastronômicos de nível médio, os quais dependiam dos consumidores vinculados às representações de empresas. Por sua vez, como divulgado por Vega (2012), os salões dos restaurantes espanhóis mais premiados mantiveram-se ativos graças aos comensais estrangeiros, e eles contribuíram para que esses estabelecimentos tenham mantido uma curva econômica ascendente no período da crise. Porém, esses restaurantes estrelados e premiados apresentam um perfil diferenciado da grande maioria, pois: seus salões oferecem poucos lugares, os quais são organizados em um cenário majestoso; suas modernas cozinhas, aliadas a uma grande brigada, permitem uma dinâmica com o uso de técnicas e criações inusitadas; a equipe, comandada por um chef renomado, agrega um sommelier, pronto a orientar as harmonizações com as opções sugeridas na carta, a qual apresenta poucas opções.

O espetáculo midiático da gastronomia, que se faz presente neste século, direciona muitos holofotes a esses estabelecimentos, mas há outros nichos que também contribuem para manter esse espetáculo ativo. Porém, para entrar nesse cenário, e ganhar a atenção devida dos canais de comunicação e de seguidores nas mídias sociais, os restaurateurs e os chefs necessitam justificar o papel diferencial que ocupam no campo ${ }^{2}$ gastronômico para ter um merecido destaque. Nesse sentido, a criação de eventos apresenta-se como um dispositivo oportuno para esses agentes lograrem seus estabelecimentos nas vitrines midiáticas e, consequentemente, obterem a atenção de consumidores comensais. (Luderer, 2013).

\footnotetext{
${ }^{2} \mathrm{O}$ conceito de campo está amparado no de campo apresentado por Bourdieu (Bourdieu \& Wacquant, 2005), e quando se trata do universo gastronômico, defende-se que esse campo seja movido pelos diversos agentes relacionados à essa área, como: chefs, restaurateurs, críticos, jornalistas, professores e alunos de gastronomia, gourmets, associações, entre outros. O Campo da Gastronomia é movido por um capital simbólico, as fichas do capital culinário, e seus agentes agitam-se em busca desse capital. O espetáculo midiático gastronômico promove o processo de trocas dessas fichas, e os agentes do campo, físicos ou institucionais, as buscam e as trocam entre eles. A quantidade desse capital está relacionada ao poder que é dado ao agente que ocupa nesse campo (Luderer, 2013).
} 


\section{REFERENCIAL TEÓRICO}

\subsection{Eventos e a comunicação}

Os eventos são opções estratégicas quando se trata de destinos turísticos e tornam-se oportunos para (pro)mover os lugares, pois eles apresentam-se como um pretexto para induzir os turistas a visitá-los (Lohmann \& Panosso, 2012). Além desse papel que ocupa enquanto relacionado ao turismo, é relevante atentar ao que frisa Getz (2008) quando se refere aos eventos, posto ele os associar à promoção, assim como ao desenvolvimento de diferentes aspectos culturais. Para ele (Getz, 2008), indiferente das tipologias nas quais um evento pode ser classificado - como as celebrações, os ritos de passagem, as competições, o entretenimento, os negócios e a socialização, por exemplo, um evento oferece um propósito singular aos sujeitos, pois se trata de uma experiência única.

Nesse sentido, e diante os diferentes dicionários da língua portuguesa que apresentam o substantivo "acontecimento" como o sinônimo do substantivo "evento", volta-se o olhar para Ranciére (1995, p. 239), um filósofo que entende o fator da singularidade do acontecimento. Para ele:

a conjunção de um conjunto de fatos e de uma interpretação que designa esse conjunto de fatos como acontecimento singular. Em outras palavras, é a conjunção de um conjunto de fatos e uma subjetivação. Não há acontecimento sem sentido de acontecimento, sem subjetivação de acontecimento.

Por sua vez, Queré (2012, p. 21), ao conferir a semântica da palavra acontecimento, a expressa como "o que vem de fora, o que surge, o que acontece, o que se produz, o excepcional que se desconecta da duração". Ou seja, essas interlocuções demonstram a ampla possibilidade de interligação no que se refere ao evento enquanto um acontecimento, no entanto, este estudo limita-se a tratar do substantivo evento a partir de uma de suas especificações, divulgadas no dicionário Houaiss: "regionalismo: Brasil - acontecimento (festa, espetáculo, comemoração, solenidade, etc.) organizado por especialistas, com objetivos institucionais, comunitários ou promocionais".

Esse conjunto de exemplos relacionados ao evento, expressa a latente conexão do termo com a coletividade. Inclusive, apoiados em Getz (2008); Lohmann e Panosso (2012) pontuam que, no conjunto dos recursos necessários para a realização de um evento, estão incluídos os recursos humanos e os agentes, assim como o envolvimento e a participação da sociedade.

Dada essa dinâmica, pode-se inferir que um evento está relacionado a um exercício coletivo, direcionado a atender outro coletivo e, desse modo, potencializa um ambiente comunicativo, no qual se embrincam diferentes signos, expressos por diferentes linguagens. 
A ciência que se dedica ao estudo dos signos é a semiótica, e ela "visa uma análise sistemática dos sistemas simbólicos, em geral, dentre os quais a linguagem [...]" (Chizzotti, 2006, p. 125). Porém, é importante esclarecer que a linguagem estudada por essa ciência está além da verbal, pois, como explica Santaella (2012, p. 02):

Em síntese: existe uma linguagem verbal, linguagem de sons que veiculam conceitos
e que se articulam no aparelho fonador, sons estes que, no Ocidente, receberam uma
tradução visual alfabética (linguagem escrita), mas existe simultaneamente uma
enorme variedade de outras linguagens que também se constituem em sistemas
sociais e históricos de representação do mundo.
Portanto, quando dizemos linguagem, queremos nos referir a uma gama
incrivelmente intrincada de formas sociais de comunicação e de significação quê
inclui a linguagem verbal articulada, mas absorve também, inclusive, a linguagem
dos surdos-mudos, o sistema codificado da moda, da culinária e tantos outros.
Enfim: todos os sistemas de produção de sentido aos quais o desenvolvimento dos
meios de reprodução de linguagem propiciam hoje uma enorme difusão.

Ciente dessa ampla potencialidade da linguagem, na qual os signos estão plenamente envolvidos, compreende-se a explanação apresentada por Chizzotti (2006, p. 125) quando referencia o conceito: “o signo é algo que 'está para alguém no lugar de outra coisa sob algum aspecto'[e] não é possível pensar sem os signos, mas um signo é essencialmente incompleto porque requer um interpretante ou contexto". Ou seja, o signo é contextualizado na relação humana e, por sua vez, está na cultura, e quando desenvolvido e expresso na linguagem é validado. Com isso, desenvolve-se uma melhor leitura dos fenômenos culturais ao conferir, compreender, interpretar e analisar os signos que movem a linguagem.

É cabível estudar os eventos nesse prisma, mas, para tanto, é importante compreender os signos relacionados a eles e a linguagem do coletivo que os cercam, conferindo as genes e o modo como os agentes dialogam com os signos e emitem seus discursos. Ou seja, trata-se então de dar atenção à semiosfera que, como exposto por Fontanille (2008, p. 282), “é o domínio no qual os sujeitos de uma cultura experenciam a significação".

Apoiado no semioticista russo Yuri Lotman (n.d. como citado em Fontanille, 2008, p. 283) avança sua exposição:

A experiência semiótica na semiosfera antecede, segundo Lotman, a produção dos discursos, pois ela é uma de suas condições. A semiosfera é, antes de tudo, o domínio que permite uma cultura definir-se e situar-se para poder dialogar com outras culturas. É também um campo cujo funcionamento dialógico tem por principal tarefa regular e resolver as heterogeneidades semioculturais.

(...)

Em Lotman, os movimentos e as deformações da semiosfera tomam a forma de um conjunto de traduções, de processos de difusão de formas e de mecanismos pelos quais as diferentes culturas assumem e transformam as contribuições exteriores.

Ou seja, a semiosfera pode ser compreendida como uma metamorfose no âmbito da cultura e os discursos reproduzidos nesse seio desenvolvem-se na condição das tramas dos textos 
culturais. Diante disso, percebe-se a relevante afirmação de Baitello (2005, p. 08), a qual exprime que "Comunicação e cultura constituem-se, desse modo, em esferas indissociáveis. Impossível pensar a comunicação humana sem a vertente histórica dada pela cultura”.

Por sua vez, como destacado acima, os discursos se dão com base na semiosfera e, por sua vez, enredam-se na cultura. Ou seja, eles se nutrem de diversas orientações e, para estudálos, é relevante atentar que o discurso está além das palavras e à expressão verbal, ou seja, como frisa Chizzotti (2006, p. 120), “O discurso é a expressão de um sujeito no mundo que explicita sua identidade (quem sou, o que quero) e social (com quem estou) e expõe a ação primordial pela qual constitui a realidade." Desse modo, conforme Chizzotti (2006, p. 121), a Análise do Discurso (AD) “(...) procura analisar o uso da linguagem em discursos contextualizados de pessoas que interagem, e os processos pelos quais dão forma linguística e produzem sentido na suas interações sociais".

Há um grande espectro de teorias relacionadas à AD. Algumas se debruçam sobre as normas gramaticais dos textos, e estreitam-se ao sistema semântico das línguas. Outras se voltam a um contexto cultural, observando as injunções na ordem da economia e da política, se estendendo às ideologias e contradições sociais, com vistas às repetições e omissões (Chizzotti, 2006).

Fairclough (2008, p. 92), que apresenta estudos relacionados a esse segundo grupo, descreve que "A prática discursiva é constitutiva tanto de maneira convencional como criativa: contribui para reproduzir a sociedade (identidades sociais, relações sociais, sistemas de conhecimento e crença) como é, mas também contribui para transformá-la”. Ainda, para ele (Fairclough, 2008), o discurso, relacionado à prática política ou ideológica, está envolvido com as relações de poder.

Como visto, as práticas discursivas estão inseridas na semiosfera, e nela se proliferam as mensagens carregadas de signos. Essa dinâmica comunicacional se dá de corpo em corpo, pois, como destaca Baitello (2005, p. 62), "o corpo é o começo e o final de toda comunicação". Além dessa inferência, a qual está apoiada em Harry Pross (n.d. como citado em Baitello, 2005, p. 62) estende seu apontamento, e ressalva, também apoiado em Pross, que o papel do corpo é a mídia primária, e que ele se "floresce de mil formas, se desdobra em mil linguagens simultâneas, diz uma sinfonia de mensagens em cada atitude". Por sua vez, conforme exposto por Baitello (2005), a mídia secundária seriam as ferramentas inseridas na cultura, as quais cobrem os corpos e os prolongam, como os aparatos e adornos e as cores neles expressas, por exemplo, sendo a própria escrita destacada como um exemplo de prolongamento do corpo. Por sua vez, a mídia terciária escapa das condições de relação com o 
corpo, pois, como explica o autor (2005) ela se representa nos aparatos elétricos-eletrônicos, e são eles que codificam as mensagens. Para ele, essa condição carrega um poder de magia, porque:

(...) A mídia terciária possui um alcance espacial impensável nos outros tipos de mídia que exigem o transporte ou do corpo ou de um suporte de sua mensagem. A mídia terciária transporta impulsos que se transformam em mensagens perceptível no aparato receptor. (Baitello, 2005. p. 74)

Ao atentar para essa relação triádica defendida por Pross e citada em Baitello (2005), é prudente perceber as diferentes situações às quais são expostas as mensagens para desenvolver as devidas análises semióticas, assim como a AD.

No tocante à mídia terciária e, mais especificamente, às mídias de informações, por exemplo, Charaudeau (2009, p. 21) enfatiza sobre a lógica econômica e a simbólica como fatores que implicam no curso de suas mensagens, pois, para ele, sob um ponto de vista empírico, um organismo desse segmento age como uma empresa e, por sua vez, tem "vocação [para] participar da construção da opinião pública”. Nesse sentido, ao debruçar em suas análises, cabe ao investigador dar atenção a esse aspecto, pois, o autor destaca que:

[o discurso informativo] tem uma posição central, na medida em que os discursos demonstrativos, didático e propagandista compreendem de algum modo uma parte de atividade informativa. E isso confere ao sujeito que procura seduzir, persuadir, demonstrar ou explicar uma posição forte de autoridade, pois em todos os casos é detentor de um saber que o outro não possui (Charaudeau, 2009, p. 63).

Na dinâmica aplicada pelos meios de comunicação, cabe a aplicação de dispositivos que, como armadilhas, são utilizados no processo de comunicação para convocar a atenção do público e selar com ele um contrato comunicativo. Para tanto, alguns agentes são eleitos, como aqueles que ganham mais visibilidade, como as celebridades, os especialistas, por representarem a voz do saber, ou, ainda, os cidadãos, que emprestam suas vozes no sentido de testemunhar suas experiências, por exemplo. Além dos textos verbais midiatizados, é preciso reservar um olhar atento ao cenário no qual os agentes são ilustrados, pois ele compõe um sistema semiológico para ser codificado (Charaudeau, 2009; Prado, 2013).

Essa constelação de cuidados a serem visualizados num processo de $\mathrm{AD}$, ganha representação e dinâmica numa investigação, que se amplia quando posta de mãos dadas com a semiótica. Ambas, que primam considerar a linguagem como fator de conexão com a estrutura social, ainda resguardam a possibilidade de um estudo desenvolvido com alicerces que permeiam o desenvolvimento crítica entorno da ativa relação social que se organiza para um evento. 


\section{METODOLOGIA}

O desenvolvimento deste trabalho teve início no segundo semestre de 2011, quando a autora, em função de um doutorado sanduíche, deslocou-se para Tarragona, com o propósito de desenvolver um trabalho de campo, qualitativo, o qual teve o apoio da Antropologia da Alimentação. No processo da pesquisa da tese (Luderer, 2013), a qual buscava conferir o papel dos chefs celebridades na construção do espetáculo midiático entorno da alimentação contemporânea, foi cabal a aproximação da pesquisadora junto de ambientes e agentes que se ocupavam e se relacionavam com o cenário da gastronomia catalã.

Ainda que a cidade de Tarragona não estivesse inserida no circuito da constelação dos renomados chefs, os quais contribuíam para mover um turismo gastronômico internacional na Catalunha, nesse município havia dezenas de casas de restauração, as quais primavam por suas produções e serviços.

A inserção nessa cidade oportunizou conhecer e conferir esses estabelecimentos e os agentes que os moviam, assim como acompanhar os diferentes eventos gastronômicos por eles promovidos. Ao assumir o papel de citadina e consumidora, mas sem perder o olhar curioso de pesquisadora, acompanhado da política de estranhamento e interesse pelo novo e pelo outro, os elos foram sendo feitos com essa comunidade.

As estratégias para a aproximação junto aos agentes corriam ao natural, muitas vezes. Ao conhecer um gourmet em um passeio histórico, em pouco tempo já se tinha acesso aos seus pares: um grupo de comensais dedicado a visitar os melhores restaurantes da Espanha. $\mathrm{Ou}$, uma colega em classe, que trabalhasse em uma das casas de restauração, levava ao encontro dos diferentes profissionais da área. Esses, por sua vez, direcionavam a pesquisadora a outros de seus pares. Nesse ciclo, a rede de contatos se fazia, e os vínculos eram ampliados, assim como a confiança na pesquisadora, como no trabalho que estava a ser desenvolvido.

Durante a estância de 11 meses em Tarragona foi recolhida dezenas de materiais publicitários, os quais anunciavam as diferentes propostas gastronômicas, promovidas pelas associações de restaurantes da cidade. Essas promoções também oportunizavam a visita aos estabelecimentos e conhecer outros agentes e espaços que, por suposto, procediam em novas percepções.

A relação de informalidade e proximidade criada com os atores relacionados ao meio gastronômico de Tarragona criou a possibilidade de conferir algumas micro histórias, e foi por esses repertórios que alertaram sobre o mal estar gerado pela crise econômica, o qual se instalado naquela comunidade. Ou seja, o mergulho em campo e os numerosos contatos, 
aliados à relação com os sujeitos em diferentes graus de intensidade, permitiram que acontecesse esse avanço para galgar em busca desse tema.

Por esse caminho metodológico também foi possível perceber o papel que esses agentes ocupavam no Campo da Gastronomia, e conferir como eles se moviam nesse contexto.

Esse conjunto de mensagens foi aliado às publicadas em redes sociais ou páginas virtuais de instituições, como em algumas trocas de e-mails, além de entrevistas. Esse grupo de mensagens foi aliada a doze entrevistas formais, procedidas em 2014, quando houve uma volta ao campo, com o interesse de investigar, junto aos agentes da gastronomia catalã, sobre a crise econômica pela qual haviam passado.

Quanto às análises, elas foram desenvolvidas a partir dos textos observados, conferidos, registrados e selecionados em campo, os quais destacaram inúmeras fotografias e filmagens captadas, mensagens divulgadas em suportes impressos e virtuais e, o cuidadoso apreço às transcrições das entrevistas. Com esse conjunto, foram analisadas as mensagens dos entrevistados, pautadas em seus discursos, os quais são observados e conferidos, a partir de suas lógicas e escolhas por significantes, além de outros signos e as possibilidades de seus significados quando expressos no contexto. Importante salientar que, ainda que as entrevistas formais tenham sido desenvolvidas, e cuidadosamente gravadas, filmadas e transcritas, os momentos de interação menos encenados, os quais deixam de acuar os agentes com questões, foram fundamentais para erigir as considerações devidas neste trabalho, pois essas mensagens também expressam seus discursos, suas escolhas e suas práticas sociais.

\section{ANÁLISE E DISCUSSÃO DOS RESULTADOS}

\subsection{Uma cidade movida por eventos, numa cultura movida pela comida}

Com a longa estada em Tarragona, aliada às futuras visitas à cidade, foi possível presenciar vários eventos gastronômicos, os quais apresentavam diferentes características e dinâmicas. Ao observá-los, conferi-los e estudá-los, verifica-se as razões que os levaram a ser criados e mantidos no calendário. Os motivos são diversos, e estão além dos interesses voltados ao capital e ao turismo, pois também são movidos pelo empenho dos agentes em manter suas memórias vinculadas à cultura na qual estão imersos.

É comum que as festividades promovidas por esse município estejam atreladas à gastronomia e essa constante relação justifica-se quando se confere a importância que tem a mesa para os catalães. Independente do seu tamanho e do número de pessoas envolvidas, no 
momento da refeição esse objeto está no centro da união entre as pessoas. Essa representação da mesa e do comer em comum pode ser entendida pelo vínculo histórico que a cidade apresenta com os romanos, pois Plutarco já destacava como máxima a relação da mesa com a alimentação no período das primeiras civilizações. Flandrin e Montanari (1998, p. 108) enuncia essa frase de Plutarco: "Nós não nos sentamos à mesa para comer, mas para comer junto".

Outro aspecto a ser considerado na Catalunha quando se refere à alimentação é o seu avesso, ou seja, a escatologia. A cultura catalã expressa sua relação intrínseca com o exercício da defecação em várias festas. No período do Natal, por exemplo, há os bonecos caganers, réplicas de diferentes personagens relacionados à política e à cultura, representados com as calças baixas, prontos para o ato da defecação. As miniaturas são comercializadas no período do Natal, pois são inseridas aos demais personagens dos presépios. Essas figuras, que popularmente são conhecidas por oferecer sorte, estão vinculadas ao campo, relacionadas ao agricultor que defeca na terra para ter um solo mais fértil. Outra representação desse estilo e também presente no período natalino é o Tió, um tronco de árvore que, na atualidade ganhou feitio de um boneco, pois passou a ter pernas, uns caras desenhados - a qual inclui uma boca - e acessórios, como uma manta e um gorro vermelho. No mês de dezembro Tió é colocado nas casas onde há crianças e elas são estimuladas a alimentá-lo até a véspera de Natal, quando, devidamente nutrido, o boneco está pronto para "cagar" os doces e bugigangas ansiosamente aguardados pelos pequenos. Para tanto, as crianças cantam tradicionais versos relacionados ao Tió, o qual defeca para elas as quinquilharias ${ }^{3}$.

Como salienta Ustrell (2011), os catalães apresentam uma atração pela defecação, o que é visto nas poesias, pinturas e ditos populares ${ }^{4}$. As doçarias também expressam essa cultura, e apresentam diferentes propostas gustativas em formato de fezes em suas vitrinas.

Ao conferir essas representações culturais escatológicas - como o tronco ou a associação das fezes com um solo fértil -, pode-se inferir a estreita relação que essa comunidade mantém com o campo e, por sua vez, com os alimentos dele obtido. Esses textos culturais aproximam os citadinos do meio rural, e podem ser passíveis para provocar os discursos expressos de vários agentes da gastronomia catalã quando demonstram a relevância da sazonalidade dos produtos que são levados à mesa.

\footnotetext{
${ }^{3} \mathrm{Na}$ Catalunha, a troca de presentes é feita no dia de Reis, seis de janeiro.

${ }^{4}$ Qui mengi molt i cagui fort no há de temer la mort (quem come muito e caga forte, não há de temer a morte); Val més um bom cagar que um bom dinar (vale mais uma boa cagada, do que um bom almoço); Ni pujar a cavall sense cagar, ni feina de força sense esmorçar (nem subir ao cavalo sem cagar, nem fazer força sem o café da manhã); según come el mulo, caga el culo (de acordo come se como a mula, o cu caga) (Caganer y Tió, 2013).
} 
Além das cartas dos restaurantes, a dinâmica relacionada ao cronograma dos eventos gastronômicos enuncia essa relevância. Ao comensal que busque provar um típico risoto de cogumelos ou um calçot ${ }^{5}$, teria que prova-los no inverno. Se a preferência fosse pelos pescados azuis, no início do verão ocorriam as jornadas gastronômicas dedicadas a eles, e os caracóis podiam ser degustados depois, em setembro, quando eram inseridos como parte dos festejos de Santa Tecla, a padroeira da cidade. Nessa festa, inclusive, a cidade é regada por chartreuse, um licor francês especialmente elaborado para esse festejo e aplicado em diferentes menus propostos pelos restaurantes no período do evento.

Essa dinâmica festiva, acompanhada de distintos sabores e direcionada por um cronograma, move a cidade e os restaurantes. Cria-se um repertório mnêmico, ancorado nos rituais e suas representações, as quais incluem a mesa com os produtos sazonais. Com isso, poucas celebrações escapam dessa lógica binária da festa e da comida, como era o caso do tradicional concurso de fogos de artifício, um evento realizado desde 1990 e festejado, anualmente, no início do mês de julho, mas, em 2010, ganhou a presença do sabor e da mesa.

\subsection{Um jantar sob a luz dos fogos de artifício}

Dentre as entrevistas desenvolvidas em 2014, quando se buscava conferir o efeito da crise econômica para os restaurantes de luxo catalães, salientaram-se, entre as narrativas, os esforços da equipe da $\mathrm{ARPA}^{6}$, por propor ao setor de turismo da cidade de Tarragona a realização do evento Sopar sota els focs- jantar sob os fogos (Luderer, 2015). O resultado foi positivo e, com isso, sua primeira edição ocorreu em 2010 e, ao verificar o calendário cultural da cidade de Tarragona (Concurso internacional, 2019), já se nota a menção da participação da ARPA para o evento em 2019. Com isso, confere-se que essa iniciativa já está por completar sua décima edição.

A ARPA é uma associação de restaurantes que estão situados na parte antiga da cidade, a Parte Alta, onde estão relevantes construções históricas do Império Romano,

\footnotetext{
${ }^{5}$ Estilo de cebolinha, assado em churrasqueira e consumido com o tradicional molho romesco. Há competições e festas da Catalunha relacionadas ao consumo desse produto.

${ }^{6}$ Há três associações de restaurantes em Tarragona, as quais se tornam responsáveis pela dinâmica de muitos eventos gastronômicos da cidade: a Asociación de Restauradores y Comercio del Serralho (ARCS), a qual está associada à duas dezenas de restaurantes fixados junto ao bairro marítimo do Serralho (L'Associació, 2019); a Asociación de Restaurantes de Tarragona ensanche (ART(e)), a mais nova das três, e é mantida por outra dezena de restaurantes locados no centro da cidade (Asociación de Restaurantes, 2019); e a Associació de Restaurants Part Alta (ARPA), à qual estão vinculados nove estabelecimentos situados na parte alta da cidade (Part Alta, 2019).
} 
incluindo a Catedral. Na rua junto a esse ícone arquitetônico está locado o restaurante AQ, dirigido pelo casal Ana y Quintim.

Quintim domina o salão e o tema dos vinhos, e Ana é a chef, e quando a crise econômica alcançou o pico, a brigada era reduzida aos dois, quando muito, um cozinheiro auxiliar e um ajudante para o salão, o qual era chamado esporadicamente. Os clientes tornaram-se escassos nesse período, incluindo os relacionados às pessoas jurídicas, os quais eram relevantes para a casa. As promoções eram feitas como fórmulas para atraí-los, mas havia um limite para tanto, pois Ana resguarda o comprometimento com a qualidade de suas produções. Nas entrevistas, Ana expressava desolada, o quanto duro foi esse período, pois se via um sonho conquistado sendo desfeito. Por sua vez, o problema era maior, porque o mote que os assolavam também provocava o mesmo cenário nas casas vizinhas.

Em 2009, Quintim busca parcerias junto aos seus colegas, e organizam a ARPA. O grupo ampliou, e chegaram a agrupar 25 restaurantes da Parte Alta com o propósito de organizar um festival gastronômico, o l' espineta amb caragolins ${ }^{7}$. Via-se com esse evento um movimento no qual as equipes de restaurantes luxuosos aproximavam-se da população. A produção servida em descartáveis e por preços populares era consumida no entorno da Parte Alta da cidade, junto da Catedral. Além de serem usadas as cadeiras e mesas espalhados nessa área, a própria escadaria da igreja era usada para acomodar o público comensal. Ao conferir esse evento em 2011, foi possível perceber o efeito de socialização entre as pessoas que o momento oportuniza.

Além desses eventos, a partir do período da crise econômica, a ARPA tem organizado jornadas gastronômicas, as quais ganharam proeminência para os restaurantes e para a cidade, como o Somriu a la Crisis - sorria para a crise - , criado em 2011 e já está na sua nona edição.

Essa proposta é promovida em fevereiro, um dos piores meses de movimento para o setor $^{8}$. Para atrair os comensais, os menus criados, especificamente para esse período, apresentam preços menores que os comumente praticados, além de ser entregue uma segunda garrafa de vinho após a refeição para o cliente, do mesmo rótulo escolhido durante a refeição. Essa oferta é apoiada pelos distribuidores de vinhos dos restaurantes.

\footnotetext{
${ }^{7}$ Prato típico de Tarragona, feito com atum e caracóis, e relacionado à festa da patrona da cidade, Santa Tecla, comemorada em setembro. Foi conferido que a promoção popular do prato, como parte do evento, esteve presente no evento em 2018 (Diez momentos imprescindibles para vivir Santa Tecla en Tarragona, 2018). No entanto, não há referência a ele no calendário do portal de turismo de Tarragona para 2019.

${ }^{8}$ Segundo expuseram alguns atores nas entrevistas, além do inverno inibir as pessoas a saírem de suas casas, janeiro é um mês de gastos extras, quando se compra presentes em função do dia de Reis , também, por suceder as festas Natalinas.
} 
O Sopar sota els focs apresentou uma dinâmica diferente, pois o evento ocorre em outra zona da cidade, abaixo da Parte Alta, no Passeio das Palmeiras, o lugar onde o público se posiciona, estrategicamente, para assistir ao espetáculo do concurso internacional de fogos de artifício.

O evento acontece no início do verão, quando os dias são mais longos e, o espetáculo de fogos necessita da escuridão da noite para acontecer. Logo, como relataram Quintim e Leo Vidal $^{9}$, o show terminava tarde, inibindo que o público se sentisse atraído para subir à Parte Alta para jantar. Com isso, segundo suas declarações, surgiu a ideia dos restaurantes da ARPA descerem, ou seja, levarem os restaurantes para onde estava o público.

Pode-se inferir que há uma inversão social nessa troca, vinculada à pirâmide social. Ou seja, a Parte Alta, representada pela onipotente arquitetura da Catedral, onde estão os restaurantes luxuosos que atraem uma elite, move-se para a base, o espaço do povo, das massas, dos comuns.

Os valores praticados ${ }^{10}$, as propostas diferenciadas dos menus, agregados à decoração dos restaurantes vinculados à ARPA contribuem para serem notados como espaços destinados a uma elite e para serem buscados em ocasiões especiais. Esse era o eco que se ouvia no período no qual esta pesquisadora esteve em campo. As entrevistas com alguns comensais ou mesmo com a equipe desses estabelecimentos também expressaram essa mensagem, a qual se repercutia no senso comum. As próprias palavras de Alba Catalã ${ }^{11}$, que foi camareira do AQ e hoje é a responsável pela publicidade da ARPA, descreve essa impressão, pois no seu relato, quando expõe o momento em que buscava um posto de trabalho, afirma: "me chamava a atenção esse lugar, mas me provocava distância, porque eu o via como um espaço bastante elitista".

O Sopar sota els focs teve o apoio do setor do turismo do município e, para Quintim e Vidal, a sua criação foi uma oportunidade de mostrar o trabalho que os restaurantes do ARPA desenvolvem, assim como promover as suas propostas gastronômicas para um público que pouco as conhece. No entanto, também é relevante salientar que o evento tem contribuído para seus estabelecimentos manterem uma féria ativa durante os quatro dias do festival.

\footnotetext{
9 Vidal é mexicano e foi cozinheiro do AQ no período da crise, quando, por esse motivo, foi dispensado. Atualmente é chef de seu próprio restaurante, Frida, o qual também faz parte da ARPA.

${ }^{10}$ Um menu completo, que ronda a média dos 50 euros, nas jornadas gastronômicas custa próximo de 30 euros, e as casas que praticam valores próximo dos 30 euros, passam a comercializar suas propostas por 19 euros.

${ }^{11}$ As entrevistas foram elaboradas em espanhol e a tradução é de responsabilidade da autora.
} 
A entrevista com Alba Catalã, uma agente que os acompanha há mais de uma década, esclarece muitos aspectos sobre esse evento, como da crise econômico com a qual esses atores vinculados à ARPA tiveram que lidar. Segue parte de suas narrativas:

- (...) comecei a trabalhar nos finais de semana ali [no restaurante AQ]. Antes de começar a crise. Antes de 2008. [quando], realmente, havia muito trabalho!

- (...) Fui por três ou quatro meses a Buenos Aires e, quando voltei tudo estava sob o pânico da crise. Então me dei conta do antes e depois. Uma maneira muito brusca. (...) enquanto, por exemplo, eu trabalhava de cinco a seis dias, pois eles me chamavam: 'Tem muita gente, ${ }^{12}$ podes vir agora ao meio dia?' Eu ia. Mas tudo isso desapareceu. Quando voltei, realmente vi uma mudança incrível. E ainda eu tinha outro trabalho em um hostel, e aconteceu o mesmo. Quando fui viajar, por três meses, tanto Quintim como o outro chefe me disseram 'não se preocupe, pois quando voltar te ofereceremos trabalho', mas quando voltei, me disseram: 'Alba, sentimos muito, mas está tudo fatal.'. Assim, enquanto ia trabalhar 23 dias, passei a ir dois ou três.

Alba relata que a partir do evento Somriu a la crisis foi quando passou a colaborar com a ARPA no papel de publicitária, e explica parte do propósito da associação:

- A associação, pouco a pouco foi crescendo, e a partir daí [do Somriu a la crisis] começaram a desenhar ações para os restaurantes participarem, e muitas jornadas gastronômicas não tinha um êxito específico, tampouco nós buscávamos um volume de pessoas, pois o que [a associação] queria era destacar a Parte Alta como referência gastronômica, através de jornadas vinculadas muitas vezes ao produto da cidade, como o pescado azul ou o bacalhau.

E na sequência de sua narrativa, confere-se melhor o desenvolvimento do Sopar sota els focs:

- E logo se mostraram outras ações que tiveram muito êxito e que vem crescendo exponencialmente nos últimos anos. Uma delas é o Sopar sota els focs, que está na página da ARPA, [que ocorre] na semana dos fogos de artifício, em julho, [quando] os restaurantes vão ao espaço das Palmeiras, junto ao Mediterrânico, e fazem, no formato de porções ou tapas, pratos por cinco euros. No primeiro ano (2010) foi um desastre e não foi quase ninguém (...). Não funcionou porque fizeram [um esquema de] uma compra mínima de 25 euros, com [direito a] dois ou três pratos e bebidas, e a compra feita de uma só vez é sempre mais complicada (...). E nesse formato não funcionou. Então, no ano seguinte (2011) o que fizemos: entrava todo mundo que quisesse e cada prato custava cinco, e uns a dois ou três euros,

$12 \mathrm{O}$ comum nesses estabelecimentos é que os clientes façam reservas, o que permite que a equipe possa programar o tamanho da brigada a trabalhar, de acordo com a programação da agenda. 
aproximadamente. E, bem, foi um êxito! E este ano (2014) o que passa é que não se pode absorver mais pessoas por não ter espaço e tempo. O número de pratos, não me lembro bem, mas há 900 cadeiras, mais as pessoas que comem em pé, mais as pessoas que vão e voltam. Por cinco noites!! Cada ano vai variando, mas, [são] quatro noites de fogos, e neste último ano (2014), ainda que na terça-feira não haja os fogos, nós fizemos a festa inaugural, já que temos toda a estrutura montada para fazermos o evento. Não sei quantos pratos que vendemos, mas...muitos.

(...) Tivemos dias de vento e chuva, e foram vendidos 200 pratos a menos que no ano passado. Se tivesse um bom tempo se teria vendido, seguramente, uns $30 \%$ a mais.

Quanto ao motivo que leva o público ao evento e seu consequente êxito, Alba responde: 'indubitavelmente, a grande maioria busca o preço'.

\section{E continua:}

- E mais, não sendo o preço, o que costuma ser é poder provar a cozinha dos bons chefs, e dos restaurantes que têm prestigio a um preço mais baixo possível. O mesmo [que aconteceu] quando começamos, há quatro anos, na Parte Alta, o Somrie a la crisis $^{13}$.

Quanto aos aspectos negativos dos eventos, Alba ressalva as queixas de alguns comensais que questionam os valores praticados fora do período promocional, mas alega a impossibilidade para tanto, pois, com base em alguns ingredientes que se usa, os custos de determinadas propostas, apresentadas nas cartas, tornam-se impraticáveis por valores menores para manter os estabelecimentos. Assim, para esses eventos, sem perder a qualidade dos ingredientes, os pratos são criados para poder alinhar os custos de acordo com os preços propostos.

Outro aspecto que pode ser nocivo é o factível efeito dos eventos atrair um grupo de clientes que se movem exclusivamente para capturar as ofertas. No entanto, segundo Alba, Quintim e Vidal é possível detectar nos salões dos restaurantes muitos clientes novos, que se tornam fieis, que surgiram a partir das promoções.

Não há números precisos, mas Alba atreve-se a apontar algumas categorias de comensais que, segundo ela, movem esses estabelecimentos relacionados à ARPA, como: o cliente "super fiel" ao restaurante e à sua cozinha, e os frequentam com assiduidade; os que se dedicam ao turismo gastronômico, como grupos de estrangeiros que vão à cidade com o

13 Alba expõe os números recordes deste evento alcançado em 2014, quando 14 restaurantes comercializaram dez mil menus, e a proposta da jornada, prevista para três semanas, se ampliou para quatro para atender a demanda. Para ela seria uma das promoções com maior êxito. 
propósito exclusivo de ter uma refeição em um dos restaurantes; o comensal pontual, ou seja, o que recorre ao restaurante em datas especiais, e faz disso um ritual; e outros, que chegam ali pela casualidade, como pelos eventos promovidos por empresas ou é levado por um conhecido ao lugar.

Diante das categorias apontadas por ela, nota-se que está ausente nessa lista os que fariam jus aos eventos promovidos, porém, é frágil afirmar que eles estariam fora desse contexto.

Ainda que assim o fosse, confere-se uma gama de aspectos positivos relacionadas às promoções e aos eventos, como a possibilidade de oferecer momentos de ócio para a comunidade, por exemplo, num espaço caro ao contexto da paisagem de Tarragona. No (re)encontro dos cidadãos e turistas, junto ao público cenário das Palmeiras e do Mar Mediterrânico, sentados às mesas para degustar a gastronomia local, os estouros dos fogos passaram a representar mais do que a competição ali envolvida, mas a própria alegria que contagia a comunidade por ali estar ${ }^{14}$.

Inclusive, dentre as várias convocações publicitárias para divulgar o Sopar sota els focs, como faixas espalhadas pela cidade na cor vermelha, chamadas nas mídias sociais dos restaurantes e manchetes divulgadas pelos meios tradicionais de comunicação, salienta-se a corrente de comunicação verbal entre os cidadãos, que encontram no momento a oportunidade de expressar os sentidos: cheirar e experimentar novos sabores, ver e ouvir as cores dos fogos e, também, tocar os amigos e familiares nesse momento de festa.

Ainda, a dinâmica criada para o Sopar sota els focs enuncia a relevância da parceria entre os agentes do setor público e privado e, assim como salienta Costa e Sonaglio (2017):

No turismo essa gestão em parceria pública e privada tende a ser muito positiva. É
preciso entender que as atuações não se sobrepõem, mas se complementam. Ao
poder público compete a elaboração das políticas, a manutenção da ordem social e
do progresso econômico, a salvaguarda do patrimônio natural e cultural entre outras
ações que dependem dele para acontecer. Ao privado, cabe levantar demandas,
exigir implantações, assistir ações, enfim, corroborar e assumir protagonismos para
o desenvolvimento da atividade (Costa \& Sonaglio, 2017, p. 110).

No mais, o cenário da crise econômica na qual os agentes viviam quando deram início a esse evento, assim como os demais desenvolvidos pela ARPA, demonstra que seus agentes dilataram um exercício de resiliência, ou seja, diante do estado vulnerável que foram expostos, tiveram a capacidade humana de se recompor. Costa e Sonaglio (2017, p. 110), ao expor sobre a resiliência destacam que "ela está intrínseca na capacidade do ser humano de se

${ }^{14}$ Durante a estada para a pesquisa em campo, foi possível conferir a edição desse evento de 2012, no qual a alegria é instalada, contagiada pela (re)união de pessoas vindas de outras regiões e de todas as gerações. 
recompor de eventos que fogem ao seu controle e que o deixa vulnerável. Desta forma, ser resiliente é, sobretudo, ser capaz de perpassar um trauma (não se deixando sucumbir a ele) e superá-lo".

Por fim, o que se viu nesse cenário de crise econômica e criação de eventos, acima de tudo, foi um fenômeno de consumo, e ainda que se compreenda que a complexidade faça parte desse prisma, torna-se pertinente refletir sobre algumas palavras de Desjeux (2011) no que se refere a esse conceito, pois, para esse autor, o consumo é:

(...) ao mesmo tempo fonte de distinção e de integração social; logo, a um só tempo fonte de tensão entre grupos sociais, bem como de sociabilidade e de troca. A vida social é feita de competição e de cooperação, de autonomia e de controle, de hierarquia e de comunidade, e o consumo (...) está no centro dessas ambivalências (Desjeux, 2011, p. 17).

\section{CONSIDERAÇÕES FINAIS}

Há uma gama de motivos que fazem o público atender as convocações comunicacionais para participar de um evento num cenário de crise econômica, e outros tantos ensejos que estimulam os agentes a criá-lo e, neste trabalho, foi possível enunciar alguns papeis que ocupam um evento gastronômico na Catalunha, quando inserido nesse espectro que contribui para um mal estar social.

Diante da análise procedida, confere-se que os eventos podem ser considerados como um dispositivo que contribui para estimular os agentes sociais da gastronomia a se aliarem e, com isso, terem um melhor desempenho profissional num cenário de crise econômica. No mais, a criação e execução de um evento relacionado à alimentação pode ampliar a relação entre o poder público e o privado, assim como acelerar o consumo dos cidadãos e turistas. Por certo, como já se faz conhecido, também se ratifica que os eventos são passíveis para promover os momentos de ócio da população, unir pessoas e gerar o bem estar, aspectos que contribuem para amortizar o mal estar num período de crise econômica.

Ainda, um evento permite ampliar o repertório de atrações de um lugar e, por sua vez, as suas memórias culturais. Nesse prisma, assim como visto os exemplos neste estudo em relação ao tradicional show promovido pelo concurso de fogos de artifício e a proposta posteriormente criada do jantar a luz desses fogos, pode-se conferir a capacidade de um evento em se retroalimentar, como também ser fortalecido ou mesmo ser reverberado diante a promoção de outros.

No que tange ao aspecto gastronômico, eventos desse gênero oferecem a oportunidade de unirem as pessoas à mesa, e podem contribuir para resgatar a culinária local como promover novas experiências gustativas ao público, criando novas memórias e a possibilidade 
de novos hábitos para elas. Os eventos desse gênero também colaboram para manter o Espetáculo da Gastronomia ativo, ou seja, o movimento dos agentes do campo da gastronomia e a corrida em busca de suas fichas de capital culinário.

Por fim, os eventos promovem a cidade, que se agita com pessoas, turistas e cidadãos, as quais circulam, relaxam, assim como movem suas carteiras. Por outro lado, esses momentos também podem ser um refúgio ou uma oportunidade para lidar com o angustiante cenário instalado de uma crise econômica.

\section{REFERÊNCIAS}

Abend, L. (2011). Los aprendices de hechicero: Los secretos y las historias más personales de elBulli. Barcelona: Planeta.

Association of Tarragona Centre Restaurants - ART(e). (2019). Tarragona história viva. Recuperado de https://www.tarragonaturisme.cat/es/asociacion-de-restaurantes-de-tarragonaensanche-arte

Baitello, N. (2005). Iconofagia: Ensaios de comunicação e cultura. São Paulo: Hacker editores.

Bourdieu, P. \& Wacquant, L. (2005). Una invitación a la sociología reflexiva. Argentina: Siglo XXI Editores.

'Caganer' y Tió: costumbres escatológicas en la Navidad Catalana. (2013). Babylonia's Travel. Recuperado de https://babiloniastravel.com/caganer-y-tio-costumbres-escatologicasen-la-navidad-catalana/

Calendario de actividades culturales. (2019). Tarragona Historia viva. Recuperado de https://www.tarragonaturisme.cat/es/calendario-de-actividades-culturales-2019

Charaudeau, P. (2009). Discurso das mídias. São Paulo: Editora Contexto.

Chizzotti, A. (2006). Pesquisa qualitativa em ciências humanas e sociais . (2a ed.). São Paulo: Editora Vozes.

Concurso internacional de fuegos artificiales. (2019). Tarragona Historia Viva. Recuperado de https://www.tarragonaturisme.cat/en/events/international-fireworkscompetition

Costa, S. \& Sonaglio, K. (2017). Gestão do turismo em tempos de crises e vulnerabilidades. Revista de Turismo Contemporâneo. 5(1), 98-117.

Desjeux, D. (2011). O consumo-abordagens em ciências sociais. Alagoas: UFAL.

Diez momentos imprescindibles para vivir Santa Tecla en Tarragona (y diez alternativas de propina). (2018). Tarragona experience. Recuperado de

http://www.tarragonaturisme.cat/experience/2018/09/13/deu-moments-imprescindibles-perviure-santa-tecla-a-tarragona-i-deu-alternatives-de-propina/?lang=es 
El Sector Turístico en Barcelona. (2014). Ayuntamiento de Barcelona: Área de Economía Empresa y Ocupación. Barcelona. Recuperado de https://ajuntament.barcelona.cat/turisme/sites/default/files/documents/150514_el_sector_turist ico_esp.pdf

Fairclough, N. (2008). Discurso e mudança social. Brasília: Editora Universidade de Brasília. Flandrin, J. \& Montanari, M. (1998). História da Alimentação. (6a ed.). São Paulo: Estação Liberdade.

Fontanille, J. (2008). Semiótica do Discurso. São Paulo: Editora Contexto.

Gallego, E. (2018). El sector de la restauración en España. Distribución y Consumo, 154(4), 26-30.

Getz, D. (2008) Event tourism: definition, evolution and research. Tourism Management, 29 (3), 403-428.

Historia, present i futur de la barrentina. (2005). Confraria Barrentinaire. Recuperado de http://www.barretina.cat/documentacio/labarretina.htm

L’Associació. (2017). Associació de Restauració i Comerç del Serrallo - Arcs/serrallo. Recuperado de http://arcs-serrallo.com/

Leone, C. (2016). Crise e crises em Portugal. Lisboa: Fundação Francisco Manuel dos Santos.

Lohmann, G., \& Panosso, A. (2012) Teoria do turismo: conceitos modelos e sistemas. São Paulo: Aleph.

Londoño, M. L. (2013). Turismo gastronómico y desarrollo local en Cataluña: el abastecimiento y comercialización de los productos alimentícios. Tese de doutodo, Universidade de Barcelona, Barcelona, Espanha.

Luderer, C. (2013). O papel dos chefs celebridades na construção do espetáculo da gastronomia: análise discursiva das revistas de gastronomia de luxo. Tese de doutorado, Pontifícia Universidade Católica de São Paulo, São Paulo, Brasil.

Luderer, C. (2015, junho). Los restaurantes gastronómicos-la invitación al consumo en tiempo de crisis. Comunicação apresentada no IV Congreso Internacional del Observatorio de la Alimentación y la Fundación Alícia, Barcelona, Espanha.

Luderer, C. \& Soares, C. (2017). Tripadvisor e a repercussão de experiências gastronômicas mnêmicas. Revista Turismo e Desenvolvimento. 2(27-28), 293-295.

Part Alta Associació de Restaurants. (2019). Restaurants. Recuperado de https://www.arpatgn.com/

Prado, J. (2013). Convocações biopolíticas dos dispositivos comunicacionais. São Paulo: EDUC.

Queré, L. (2012). A dupla vida do acontecimento: por um realismo pragmatista. In V. França \& L. Oliveira, L. (Ed.). Acontecimento: reverberações. Belo Horizonte: Autêntica, pp. 21-38.

Rancière, J. (1995). Políticas da escrita. Rio de Janeiro: Editora 34. 
Santaella, L. (2012) O que é Semiótica. Coleção Primeiros Passos. São Paulo: Editora Brasiliense.

Ustrell, S. (2011). Escatologia catalana. El punt avui. Recuperado de http://www.elpuntavui.cat/article/387667.html

Vega, M. (2012). Las estrellas Michelin no pinchan: la alta cocina española llena sus mesas con clientes extranjeros. El País. Economía. Recuperado de http://economia.elpais.com/economia/2012/08/24/actualidad/1345810999_478492.html

LUDERER, C. A. (2019). Comer à luz dos fogos de artifício: um evento gastronômico impulsionado pela crise econômica catalã. Revista de Turismo Contemporâneo, 7(1), 28-48. https://doi.org/10.21680/2357-8211.2019v7n1ID16977 